\title{
Human mobility in the context of climate change and disasters: a South American approach
}

\author{
Lilian Yamamoto
}

\section{RESAMA (South American Network for Environmental Migrations), Brazil}

\author{
Diogo Andreola Serraglio \\ Pontifícia Universidade Católica do Paraná, Curitiba, Brazil, and \\ Fernanda de Salles Cavedon-Capdeville \\ RESAMA (South American Network for Environmental Migrations), Brazil and \\ Centre International de Droit Comparé de l'Environnement-CIDCE, Limoges, France
}

mobility in the context of climate

\begin{abstract}
Purpose - This paper aims to assess to what extent South American countries have integrated recommendations of the international agenda to address human mobility in the context of disasters and climate change in their national laws and policies.

Design/methodology/approach - This research sought to find the level of discussions around human mobility in disaster laws, NDCs and National Adaptation Plans (NAPs) by looking for a range of search terms connected to human mobility in the context of disasters and climate change, followed by the content analysis of these terms.

Findings - Some advances with regards to human mobility are already confirmed in the domestic level of South American countries through humanitarian visas to disaster displaced persons and the inclusion of the topic in the DRR, climate change laws, NAPs and INDCs/NDCs. But they have not developed specific strategies with regards to it. Hence, their advances still require that national norms and policies are harmonized with the international guidelines. This will enable to fill the protection gap of people in context of disasters and climate change.

Originality/value - The results assess the level of harmonization above-mentioned between international instruments with national policies on human mobility in the context of disasters and climate change in South America.
\end{abstract}

Keywords Displacement, Climate change, Human mobility, South America, Disasters,

Sendai Framework for Disaster Risk Reduction

Paper type Research paper

\section{Introduction}

Among the factors that impact human mobility in South America are natural hazards, the frequency and intensity of which are believed to have increased due to the negative consequences of climate change. A better understanding of the impacts of disasters and

(C) Lilian Yamamoto, Diogo Andreola Serraglio and Fernanda de Salles Cavedon-Capdeville. Published by Emerald Publishing Limited. This article is published under the Creative Commons Attribution (CC BY 4.0) licence. Anyone may reproduce, distribute, translate and create derivative works of this article (for both commercial \& non-commercial purposes), subject to full attribution to the original publication and authors. The full terms of this licence may be seen at http:// creativecommons.org/licences/by/4.0/legalcode
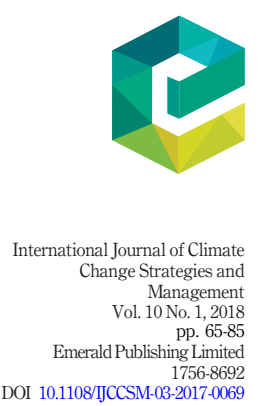
IJCCSM

10,1

climate change on human mobility is essential for attempting to introduce appropriate short-, medium- and long-term solutions to populations that can be potentially affected. Hence, states need to improve their understanding of the disaster and climate change impacts on human mobility, and to integrate these approaches into their Disaster Risk Reduction (DRR) strategies, as well as to their related norms, such as in climate change norms and policies. Human mobility is defined as:

[...] an umbrella term that refers to all aspects of the movement of people: human mobility is understood to encompass involuntary internal and cross-border displacement of populations, voluntary internal and cross-border migration and planned and consented relocation (Advisory Group On Climate Change And Human Mobility, 2015).

Forced displacement and voluntary migration are considered as two different categories, but this distinction is difficult to define, especially when people move due to presence of extensive risk. Given this, both categories can be seen as two poles along a continuum in which migrants are in the grey middle zone, where aspects of choice and coercion are mixed (Hugo, 2010).

The South American region is frequently affected by disasters and extreme events, as climate change is believed to affect the frequency and intensity of weather-related hazards (Global Platform for Disaster Risk Reduction, 2017), causing floods, droughts and hailstorms. Climatic phenomena were responsible for 88 per cent of the disasters in the region in the past five decades (Pivetta, 2016). According to the Intergovernmental Panel on Climate Change (IPCC, 2014), during the past decades of the twentieth century, unusual extreme weather events have severely affected South America, and together with the socioeconomic characteristics of population and geographic features, contribute to the strengthening of the vulnerability of human systems to natural hazards. Therefore, decadal variability and changes in extremes have been affecting large sectors of the population, especially those who are more vulnerable and exposed to climate hazards. Natural climate variability and land use change has also impacted extreme events in the region (IPCC, 2014). It is recognized that environmental changes and climate change are factors that affect migratory flows in the South American region (OIM, 2015). Empirical evidence of migration associated with climate change in South America has already been identified (OIM, 2014).

Between 2000 and mid-2015, it is estimated that around 8 million people were either displaced or evacuated in the context of disasters only in South America. The actual figures may be higher, as there is underreporting of cross-border movements in South America (Nansen Initiative, 2015). Between 2008 and 2013 Colombia was ranked as the eighth most affected country in the planet, Chile the twelfth and Brazil the nineteenth, in absolute terms of the total number of displaced people. In relative terms to each country's population at the global level, Chile occupied the fourth place and Colombia the seventh. Seismic activity in 2010 caused the highest number of displaced in Chile, while floods led to the worst disaster displacement throughout the 2008-2013, particularly in Colombia and Brazil (Nansen Initiative, 2015). For instance, in 2014, storms affected the Guayamerín region of Bolivia, which forced people into internal displacement or to cross the border into Brazil. Victims of floods in Colombia crossed the border with Ecuador (Nansen Initiative, 2015). The effects of El Niño increased the risk of droughts in 2015-2016 and brought drier conditions to South America, impacting its food security (IDMC and NRC, 2016). Cities in South America are exposed to the effects of climate change and disasters, though they are also the recipients of migration and concentrate 83 per cent of the population in the continent (Warn and Adamo, 2014). Research suggests that much of the climate-related migration in South America is directed toward urban areas (Thiede et al., 2016). Hence, the current situation requires 
governments to enhance measures that promote domestic policies and norms to address that kind of mobility.

The available literature on environmental change and migration in Latin America confirmed that most displacements occur over short distances (Cantor, 2016), towards urban centres, and, in the case of sudden natural hazards, usually last for a short time (Kaenzig and Piguet, 2014). Hence, most of the movements occur internally and tend to be short-termed. Although the main responsibility to protect these populations belongs to national governments, human mobility in the context of disasters and climate change has been addressed at global and regional levels.

Human mobility in the context of climate change was raised as a global concern under the United Nations Framework Convention on Climate Change (UNFCCC) in 1992. Human mobility was integrated into the UNFCCC at the 16th Conference of the Parties (COP 16, Cancun, 2010). The Cancun Agreement invites Parties to enhance action on adaptation by undertaking "measures to enhance understanding, coordination and cooperation with regard to climate change induced displacement, migration and planned relocation, where appropriate, at the national, regional and international levels” ( $\$ 14$, f). This process continued at the 18th Conference of the Parties (COP 18, Doha, 2012) with Decision 3/CP.18, which underlines the need to strengthen the understanding of how the impacts of climate change are affecting patterns of migration, displacement and human mobility ( $\$ 7$, a, vi). The Paris Agreement (2015) (COP 21) provides the creation of a Task Force on Displacement, and, most recently, at the 22nd Conference of the Parties (COP 22, Marrakech, 2016) migration has been accepted as a potential adaptation strategy of climate change. National Adaptation Plans (NAP) enable Parties to the UNFCCC to create strategies and programmes to address adaptation needs, and some South American countries have included the topic in their documents. The Paris Agreement included provisions on climate induced displacement, and at the same time that established that each Party should prepare Nationally Determined Contributions (NDCs), containing national measures to contribute to climate change mitigation and adaptation.

In the context of DRR policies, before the Sendai Framework for Disaster Risk Reduction (SFDRR) (2015), the only references to human mobility were made in the Hyogo Framework for Action (HFA) 2005, in the context of reducing the underlying risk factors: "Endeavour to ensure, as appropriate, that programmes for displaced persons do not increase risk and vulnerability to hazards" ( $(19$, ii, i). In this context, SFDRR can be considered a great step to integrate human mobility in DRR policies and measures.

Both instruments were adopted in the context of policy reform with regards to human mobility (Guadagno, 2016a), and are part a set of a range international instruments which focus directly or indirectly on human mobility, such as the new sustainable development goals (SDGs, 2015), the Agenda for the Protection of Cross-Border Displaced Persons in the Context of Disasters and Climate Change (2015), the outcome of the Nansen Initiative, World Humanitarian Summit (2016) and the New York Declaration for Refugees and Migrants 2016.

Since 2015, the international agenda started a process that promoted the topic of human mobility, disasters and climate change in various international instruments. These instruments, among other things, ask governments to enhance domestic norms and policies that address human mobility in the context of disasters and climate change. Among these instruments, the focus of this study will be the Sendai Framework and the Paris Agreement.

In the regional context, the turning point of discussions on human mobility in the context of disasters in South America was the strong earthquake which hit Haiti in January 2010. After that event, the Union of South American Nations (UNASUR), the Common Market of 
IJCCSM

10,1

the South (MERCOSUR) and the South American Conference for Migrations (CSM) have been actively raising the issue in their discussions. UNASUR, for example, made the declaration "UNASUR solidarity with Haiti: Quito's decision” in February 2010, which provided that member states would apply special procedures for the migration regularization of Haitian citizens (paragraph 6). MERCOSUR's Specialized Forum for Migration (FEM) has staged discussions on human mobility in the context of emergencies and disasters. For instance, during the 14th FEM's meeting in 2012, the Brazilian delegation mentioned the need to exchange experiences in the matter of international humanitarian assistance in the context of emergencies, and about the creation of a specific mechanism to protect people displaced by natural hazards. In the same meeting, the Chilean Government pointed out the possibility of creating migration laws to protect human mobility in the context of disasters and climate change (Mercosur, 2015). The CSM addressed the relation between migration, environment and climate change in its 15th and 16th (2015 and 2016) Meetings by suggesting that the topic should be included in the conference mandate, recognizing the need to do a study on the topic. Before this, the Cartagena Declaration on Refugees (1984) had amplified the concept of refugee. In 2014, the Cartagena +30 and Action Plan of Brazil recognized the challenges caused by climate change and natural hazards, as well as the transboundary displacement of people, inviting parties to carry out studies on the topic.

Given the increasing emphasis given at international and regional discussions regarding the identification of the complex linkages between human mobility in the context of disasters and climate change, this article aims to examine the extent to which South American countries focus on human mobility in these contexts in their national norms and policies. This article does not intend to address cross-border displacement. This research sought to find the level of discussion on human mobility in three different national instruments related to disasters and climate change: national disasters norms, Nationally Determined Contributions and National Adaptation Plans. The first step was to identify these instruments in each South American state. The second step was to look for a range of search terms connected to human mobility in the context of disasters and climate change, as migration/migrants, displacement/displaced persons, relocation, evacuation and resettlement related to disaster and climate change, as they are defined by the International Organization for Migration (OIM, 2014), followed by a qualitative content analysis (Krippendorff, 2013) of these terms in the identified documents.

The article will first analyse the treatment of human mobility in the Sendai Framework and Paris Agreement. Then, it will address disaster laws, NAPs and NDCs to assess the treatment of human mobility in national laws and policies of South American countries.

\section{Sendai Framework for Disaster Risk Reduction and human mobility}

From 2008 to 2016, 227.6 million people were displaced by natural hazards throughout the planet. Eighty-six per cent of these displacements were a consequence of weather-related disasters. In 2016 alone, 24.2 million people were displaced by disasters, a number that represents more than three times as high as that related to conflicts (6.9 million new internal displacements) (IDMC and NRC, 2017). It is important to note that discussions on human mobility have only advanced the DRR framework with the SFDRR 2015-2030 at the Third World Conference on Disaster Risk Reduction in Sendai, Japan.

The SFDRR, endorsed by UN General Assembly (UN Doc. A/RES/69/283), is a 15-year voluntary and non-binding agreement, which recognizes that states have the primary role to reduce disaster risks and that responsibility is to be shared with other stakeholders, such as local governments and the private sector. It aims, therefore, to achieve "the substantial reduction of disaster risk and losses in lives, livelihoods and health and in economic, 
physical, social, cultural and environmental assets of persons, businesses, communities and countries". The SFDRR is the successor instrument to the HFA 2005-2015: Building the Resilience of Nations and Communities to Disasters (UN Doc.A/CONF.206/6).

While the reference of human mobility provided by the HFA only relates to the recognition of forced population movements and efforts to address them, calling on states to manage risk outcomes (Guadagno, 2016a), the SFDRR broadened the topic of human mobility as the outcome of efforts made by Nansen Initiative Steering Group member states, in special, Bangladesh, Norway, the Philippines and Switzerland (McAdam, 2016). Through four priorities for action - understanding disaster risks, strengthening disaster risk governance to manage disaster risks, investing in disaster risk reduction to improve resilience and enhancing disaster preparedness for effective response and to "Build Back Better" in recovery, rehabilitation and reconstruction - the SFDRR highlights the fact that all types of migration, including those which are not disaster-related, have a resilience building potential. It also calls for the inclusion of migrants in DRR and seeks to strengthen resilience and pinpoint states, regional and international organizations and other relevant stakeholders to address displacement risk and minimise its negative consequences (IDMC, 2017). SFDRR included several paragraphs on human mobility, displacement, evacuation and relocation to improve disaster risk governance, and points out that these topics should be addressed in normative frameworks. The SFDRR has a twofold approach to human mobility:

(1) impact of disaster on migrants and migrants' participation in DRR; and

(2) forced displacement caused by disasters; the following sections deal with the various displacement phases provided for by the SFDRR.

\subsection{Pre-displacement phase}

The main scope in this phase is to minimize the risk of long-term displacement. This includes coordination with local governments to provide information on local shelters, and identification of populations at high risk that may be subject to relocation. This phase requires that countries not only focus their actions on the emergency disaster response, i.e. displacement and recovery phases, but also requires the adoption of policies and norms concerning disaster displacement to best prepare, respond and prevent. SFDRR explicitly mentions the adoption of policies and programmes addressing disaster-induced human mobility to strengthen the resilience of affected people and that of host communities (Paragraph 30 (1).

2.1.1 Participation of migrants. Migrants may face challenges in accessing resources, information and services due to limited language proficiency, which affects their knowledge of environmental conditions, institutions and markets (Guadagno, 2016b). Although the migrants' role as a preventive measure to displacement is very relevant due to the abovementioned patterns of vulnerability, there is also concern regarding the response and recovery phases. Essentially, all phases of displacement represent a challenge to migrants. Lack of communication with migrants may occur due to language barriers, differences in risk perception, differences in information sources and lack of local knowledge (Guadagno, 2016b). If a natural hazard affects a country, it is likely that migrants may be perceived by host communities as having a low-priority (Guadagno, 2016b). Given this, SFDRR explicitly mentions the role of migrants in DRR in three paragraphs. In paragraph 7, it states that governments, when designing and implementing policies, plans and standards, should engage with stakeholders, "[...] including [...] migrants". This paragraph highlights the inclusive approach that governments are asked to take, including various stakeholders. 
IJCCSM

10,1

Migrants are vulnerable since sometimes they may have an irregular status, or may have limited access to information regarding disaster prevention and management. The SFDRR recognizes them as a specific group whose need needs to be recognised in DRR policies.

The SFDRR also underscores that local authorities should be empowered through regulatory and financial means to work and coordinate with "migrants in disaster risk management at local level" (Paragraph 27 (h)). Thus, local authorities are encouraged to provide incentives for existing structures in the migrant communities to make up time and resources devoted to DRR activities, to promote participation of migrants before, during and after natural hazards (Guadagno, 2016b).

Finally, it empowers migrants because it recognizes that they have "knowledge, skills and capacities" which can contribute to improving the resilience of communities (Paragraph 36 (a) (vi)). This paragraph, hence, shows that migrants are not to be seen as mere victims but as agents that may also contribute to improve the resilience of the communities in which they live.

2.1.2 Land use and relocation. Modifications on infrastructural developments, land use in urban areas and surroundings produce changes in people's distribution and mobility (Guadagno, 2016a). That is why authorities should plan carefully the use of land, as it will impact ecosystems and can also trigger new natural hazards (Guadagno, 2016a). The SFDRR promotes land-use policy development and implementation, as well as the use of guidelines and follow-up tools informed by demographic and environmental changes (Paragraph 30 (f)). The Working session of Land-Use Planning for Disaster Risk Reduction in Sendai recognized that land use planning plays an essential role for disaster risk reduction and sustainable development (UNISDR, 2015). Land use planning is a process that determines where different socioeconomic activities, such as agriculture, housing, industry, recreation and business, should occur (World Bank, n.d.), and aims to preserve natural resources and responds to community needs. The rural-urban movement caused cities to have high densities, which increases vulnerability to environmental emergencies and climate change-related hazards. For example, informal settlements in slums do not have building codes and road maps, which will make it more difficult access to reach these regions to provide assistance during an emergency (UNEP, OCHA, 2012).

In some instances, due to the geographic and socioeconomic vulnerability of the population of certain areas, the best way to prepare for natural hazards is to promote relocation. Peninsula Principles (2013) suggest the creation of a standard criterion for lands to be used for relocation. Such criteria would encompass: current and future land use; restrictions associated with land use; habitability of the land; availability of water; vulnerability to climate or other natural or human hazards; feasibility of subsistence use, and mechanisms for individuals to decide to where they wish to relocate (Principle 11 (b)). Although these principles provide a complete guidance on relocation, they do not determine when a preventive relocation should occur, or who should make this decision, and no institutional mechanism has yet been determined to deal with this crucial topic (Bronen, 2015).

SFDRR provides the possibility of formulating "public policies, where applicable, aimed at addressing the issues of prevention or relocation, where possible, of human settlements in disaster risk zones, subject to national and legal systems" (Paragraph $27(\mathrm{k})$ ). Governments may relocate people from disaster-prone areas or due to slow-onset disasters which make life unsustainable in the area (Brookings Institute, London School of Economics, 2014). Relocation is different from evacuations because it is preventive (Brookings Institute, London School of Economics, 2014) and assume that populations are not going to be able to return to their homelands. In some instances, it results in a completely diverse lifestyle, and that is why it should only be used as a last resort. Relocation is a very complex adaptation 
strategy which requires a careful consultation with both the receiving and displaced communities, with the promotion of dialogue among all actors and parties being essential to its ultimate success (Yamamoto and Esteban, 2017). Hence, states should provide full and informed consent before carrying out plans to relocate communities (Principle 10 (b) of Peninsula Principles).

Relocation could be necessary when people live in areas prone to sudden-onset natural hazards, such as flood-prone areas; or slow-onset effects such as droughts or the salinization of water, or if a country can disappear due to sea level rise (Ferris, 2014), which could be the case of atoll island states, such as Tuvalu, Kiribati and Maldives (although it is not clear whether these islands would disappear, as much depends on the geomorphological resilience of the island and the adaptation capacity of corals, see Yamamoto and Esteban, 2017). While the first two cases apply to the South American context, slow-onset effects are less likely to prompt mass relocations, as people tend to migrate gradually to other areas and triggers such as economic and social reasons may play an important role on the decision to migrate.

\subsection{Displacement phase: evacuation}

Evacuation consists of the fast movement of people to flee from an immediate threat or impact of a disaster to a safer place or shelter. It can last from hours to weeks, and during that time procedures are enacted to save lives and minimize exposure to harm (Camp Coordination and Camp Management Cluster, n.d.). Evacuation guidance is largely provided at national level, often in the framework of civil protection and national disaster management organizations (Ferris, 2014).

Evacuation management guides people who are facing a threat out of a zone of danger, and has passive and active components. The former includes signs and you-are-here maps in the environment, and the later includes evacuation orders coming from a central command centre and trained personnel to guide evacuation flows and mobile devices (Richter et al., 2013). The SFDRR also calls states to:

[... .] promote transboundary cooperation to enable policy and planning for the implementation of ecosystem-based approaches with regard to shared resources, such as within river basins and along coastlines, to build resilience and reduce disaster risk, including epidemic and displacement risk (Paragraph 28 (d)).

The SFDRR has several paragraphs which refer to evacuation planning and displacement. To assure that people increase their chances to evacuate safely after a disaster, it is necessary to promote preparedness, response and recovery exercises, including evacuation drills, training and the establishment of area-based support systems. It also points out the need to ensure access "to safe shelter, essential food and non-food relief supplies" (Paragraph 33 (h)). Ley de Política Nacional de Gestión del Riesgo de Desastres y Sistema Nacional de Gestión del Riesgo de Desastres, Colombia (2012), Ley de Gestión de Riesgos (Bolívia) (2014), Ley que crea el sistema nacional de gestión de riesgo de desastres (SINAGERD) (Perú) (2011) and Ley de Gestión Integral de Riesgos Socionaturales y Tecnológicos (Venezuela) (2009) have specific DRR laws that encompass elements such as social participation and DRR education.

Local governments are responsible for basic infrastructure such as roads, parks and waste disposal. Their close contact with residents allows them to raise their awareness, elaborate procedures and carry out evacuations in disaster situations. Thus, SFDRR suggests that the capacity of these authorities must be strengthened to evacuate people who live in areas affected by disasters (Paragraph $33(\mathrm{~m})$ ). Temporary settlements for displaced 
IJCCSM 10,1

persons should also take into consideration in an integrated approach which includes economic and social sustainable development of the affected areas (Paragraph 33 (j)).

In the displacement phase, the fast humanitarian response is crucial to save lives, and some countries in the region grant humanitarian visas. Peru (art.59 (2) Decree 1236 of 2015) allows individuals to stay for 183 days with the possibility of extension (ICMPD, 2016). Argentina also includes:

$[\ldots]$ those people that $[\ldots]$ temporarily cannot return to their countries of origin due to the humanitarian conditions prevailing or due to the consequences generated by natural or environmental disasters caused by man (art.24 (h), Decree 616 of 2010).

Bolivia allows the admission of "displaced persons by the climatic effects, when there is risk or threaten of life, due to natural or environmental disasters” (Law 370 of 2013).

\subsection{Post-crisis phase}

The post-crisis phase requires that recovery activities are carried out. It includes planning for recovering damaged areas as well as other long-term needs, and integrated approaches should always be prioritized. That means that is necessary to pay attention to environmental, technical, economic, social and institutional concerns to ensure the best long-term results. In addition, post-disaster reconstruction and the case of temporary settlements for persons displaced by disasters should be integrated into the economic and social sustainable development of the affected areas (Paragraph 33 (j)). Reconstruction will provide direction for long-term urban development, and once the foundations for economic and urban rebuilding are established, there will be irreversible changes to a settlement. Following an integral approach can avoid that the reconstructed area transforms itself into dysfunctional urban space (IFRC and SKAT, 2012). There is a high risk that governments respond only to short-term needs and overlook a sustainable long-term approach to the development of the affected areas. Given this, displaced populations often leave new settlements and go back to their original residential areas due to failures in design, construction and delivery of the resettlement and consultation with affected people (Oliver-Smith and de Sherbinin, 2014).

Governments tend to prioritize short-term goals over long-term planning when dealing with natural hazards. Victims of droughts and floods in the Amazon were assisted by the federal government through emergency care and food items, but when the region entered the post-crisis phase, the population was not provided with any other form of assistance (Marengo et al., 2013).

\subsection{Sendai framework for disaster risk reduction in the Americas}

The American continent contributed to the process of the construction of the Agenda post2015 with seven events[1], and it is working on the implementation of the SFDRR. The First Meeting of Ministers and High-Level Authorities on the implementation of the Sendai Framework for Disaster Risk Reduction, 2015-2030 in the Americas was held in 8 and 9 June 2016 to establish the grounds of a regional plan to implement the SFDRR and discuss the integration of DRR and climate change agendas. In this meeting, the Asunción Declaration: Guidelines Towards a Regional Action Plan on the Implementation of the Sendai Framework in the Americas (2016) reaffirmed the need to enhance the Regional Platform for Disaster Risk Reduction in the Americas, although it did not mention human mobility explicitly (RESAMA, 2016). Besides, the declaration recognizes the need of governments and other stakeholders to widely disseminate strategies aligned with the Sendai Framework, and urges intergovernmental bodies to support countries to integrate disaster risk reduction considerations into national and sub-national policies. 
In these terms, the Fifth Regional Platform for Disaster Risk Reduction (DRR) in the Americas took place in Montreal, from 7 to 9 March 2017, and brought together key stakeholders and actors involved in DRR from throughout the Americas. The outcome documents from this meeting were a Regional Action Plan and a Declaration that support the implementation of the Sendai Framework in the Americas. Nevertheless, none of these documents mention the topic of human mobility, which demonstrates a lack of harmonization with the global platform for disaster risk reduction and undermines regional developments on this approach. Thus, while the SFDRR underscored the importance of the topic in several paragraphs, instruments that would respond to regional needs have so far been completely overlooked.

There is no global indicator to assess the implementation of measures concerning disaster displacement within the SFDRR, and thus, governments may choose to include displacement in their DRR targets and indicators. In the Global Platform for DRR in May 2017, the Platform on Disaster Displacement called states to establish national targets and indicators on disaster displacement (Platform for Disaster displacement, 2017). Bolivia, Brazil, Colombia and Ecuador have submitted their Sendai Framework Data Readiness Review reports, which do not include disaster displacement indicators.

\section{Human mobility in the Paris agreement}

The Paris Agreement in 2015 represents a major step forward in recognizing the linkage between migration and climate change, as it acknowledges in its Preamble:

[... that climate change is a common concern of humankind. Parties should, when taking action to address climate change, respect, promote and consider their respective obligations on human rights $[\ldots]$ (and that of) migrants [...].

The agreement provides objectives and obligations on mitigation, adaptation, loss and damage and financing. In addition, the agreement:

- requests the Executive Committee of the Warsaw International Mechanism (WIM) to establish a task force on displacement to develop recommendations to prevent and reduce the displacements caused by the adverse effects of climate change; and

- recognizes that states can contribute to the development of the migration topic in the climate negotiations in their Intended Nationally Determined Contribution (INDCs).

The WIM is the main vehicle in the UNFCCC mechanism to address loss and damage associated with climate change impacts in developing countries that are particularly vulnerable to the adverse effects of climate change.

The WIM aims to facilitate and support action to address loss and damage, improve coordination, convene meetings, provide technical guidance and support, as well as make recommendations. As such, its implementation is guided by an executive committee, which is supposed to enhance the knowledge and understanding of comprehensive risk management approaches; strengthen dialogue, coordination, coherence and synergies among relevant stakeholders; as well as enhance action and support, including finance, technology and capacity-building. During COP21, the Executive Committee was requested to establish a task force to complement, draw upon the work of and involve, as appropriate, existing bodies and expert groups under the UNFCCC - including the Adaptation Committee and the Least Developed Countries Expert Group, as well as relevant organizations - to develop recommendations for integrated approaches to avert, minimize and address displacement related to the adverse impacts of climate change (IOM, 2015). 
IJCCSM

10,1

As the (at the time of writing) ongoing task force is to deliver its results no later than the 24th Conference of Parties (COP24)[2], the Technical Meeting on the Migration, Displacement and Human Mobility, organized by International Organization for Migration (IOM) and Excom, held in July 2016 in Casablanca, recommended to the following actions:

- take into account the latest science, most recent evidence, findings and experience;

- consider approaches to avert, minimize and address displacement related to the adverse impacts of climate change on subnational, national, regional, international level;

- identify legal, policy and institutional challenges, good practices and lessons learned;

- provide opportunities for Parties to articulate their questions and needs, good practices, lessons learned; and

- share information with, complement, draw upon the work of and involve, as appropriate, existing bodies and expert groups under the Convention including the Adaptation Committee and the Least Developed Countries Expert Group, as well as relevant organizations and expert bodies outside the Convention and others.

The first draft of the Agreement provided the possibility of establishing a climate change displacement coordination facility which would assist with emergency relief for displaced people and planning relocations. However, the next draft omitted such institute due to the opposition of Australian government (Wilkinson et al., 2016).

The so-called INDCs were the basis of the parties' engagement to support the agreement, stating their national plans on tackle climate change. After the adoption of the agreement in 2015, INDCs became NDCs on the ratification of the instrument (Chazalnoël and Mach, 2016). The Nationally Determined Contributions or national climate action plans refer to national governments actions to be taken under the Paris Agreement. They are the basis of post-2020 global emissions reduction commitments and state parties are requested to describe what measures they will take to minimize emissions (Climate Policy Observer, n.d.). Including human mobility in NDCs is necessary to reduce potential future negative effects of climate change, as people are already being affected by disasters and slow degradation of the areas in which they live. Policy tools on climate change could be harnessed to address migration as adaptation strategy (Chazalnoël and Mach, 2016). All South American countries are signatory parties of the agreement, but only Argentina, Bolivia, Brazil, Chile, Guyana, Paraguay, Peru, Uruguay have ratified it. Among all the INDCs which were sent until November 2015, only 24 states mentioned human mobility.

\section{Human mobility on nationally determined contributions, disaster risk reduction laws and national adaptation plans}

The review of norms related to disaster laws, INDCs/NDCs and National Adaptation Plans in South America that encompass human mobility will demonstrate what is the stage of the policy on the topic compared to what SFDRR and PA provides on the issue.

\subsection{Human mobility in the South American Intended Nationally Determined Contributions/ Nationally Determined Contributions}

Migration and displacement are emerging issues to be considered by states in Latin America in the context of climate change legal and political frameworks (UNEP, PARLATINO, 2015). Preventive and reactive outlook on migration was taken by countries that refer to migration 
in their NDCs in South America. Uruguay intends to "strengthen climate risk management against floods, through the enhancement of vulnerable population resettlement processes and the implementation of new land-use planning measures" (Uruguay INDC UNFCCC, 2015). Colombia took into consideration its post-conflict context and stressed that "among other things, migration patterns that increase pressure on natural resources in the most vulnerable areas, often resulting in increased deforestation" (Colombia INDC UNFCCC, 2015). Venezuela INDC UNFCCC (2015) reported the plan "Gran Misión Vivienda”, created in 2010 as a response to the emergency caused by storms which affected hundred thousands of people in the poorest areas in the country, and built more than 800,000 of houses until November 2015. Suriname INDC UNFCCC (2015) recognized "the vulnerability of the coast and the ever increasing impacts on a significant percentage of the population", which posed a dilemma for the government to decide to invest in adaptation in these areas or to relocate the population at risk.

Thus, except from Venezuela, most of the countries which referred to human mobility in their NDCs have preventive aspects regarding planning relocation. Venezuela's planning on relocation, which started as reactive to the specific situation of the storms, is expected to relocate other communities in the future.

\subsection{Disaster risk reduction norms and human mobility}

Disaster risk reduction aims to minimize factors that determine economic, social and environmental impacts of hazards by providing a specific theoretical frame on these relations. It tries to understand how to reduce vulnerability and risk and to prevent these processes in resulting in the worst scenario, and, in case that the worst scenario occurs, to recover from shocks and stresses (Guadagno, 2017). Disaster norms encompass topics such as prevention, preparedness, mitigation and response. It can also include national institutions for DRM and at least some of their responsibilities (IFRC and UNDP, 2014). To analyse how disaster risk reduction norms in South American States deal with human mobility, the authors identified all national norms that regulate disaster in the region. Then, these norms were regarding the terminology that concerned human mobility. Only the legal instruments making reference to human mobility are summarised below.

Several measures for disaster management were implemented after severe natural hazards in the region, such as the earthquake of Valdivia in Chile in 1960, which triggered the creation of Law $n^{\circ} 16.262$ of Permanent dispositions for seismic cases and catastrophes (1965). Landslides, floods and an earthquake in Popayán prompted the creation of the Decree no 1547 to create the National Fund for Calamities (1984) in Colombia. An earthquake in Ancash in Peru in 1970 influenced the creation of the Decree-Law no 19338, the law of the Civil Defence System among others (Álvarez, 2016). A storm in 2005 in Uruguay drove the creation of the Law $n^{\circ} 18621$ of 2009 which established the System of Integral Management of Emergencies and Disasters Risk (Brugnoni, 2012).

Disaster laws in South American countries that address human mobility in their domestic legislations focus mainly in relocation and evacuation, encompassing both predisplacement and displacement phases. Bolivia's Risk Management Law ( $\mathrm{n}^{\circ}$ 602, 2014) establishes the possibility of "relocation of human settlements" to reduce potential and existing risks (art.22, a, II). Disaster risk management in Colombia is a complex matter due to the high rate of migration and unplanned urbanization, which is worsened by the armed conflict in the rural areas (SNPAD, 2008). Colombia (2012) refers to "relocation of human settlements addressed to disasters situations" in its National Policy of Disaster Risk Management and National System of Disaster Risk Reduction Law ( ${ }^{\circ} 1523$ of 2012). In the same instrument, it provides that public entity buildings in educational and health, 
IJCCSM

10,1

including hospitals, security and welfare sectors that are located in high-risk areas will be relocated. Peru enacted the Law $n^{\circ} 29869$ in 2012, which establishes the resettlement of population located in regions of high risk and provides voluntary and involuntary resettlement.

The history of Venezuela's civil protection dates back to the earthquake of 1812 and the displacement of people to the eastern part of the country, which made the government create the Civil Defence department (Álvarez, 2016). Venezuela enacted the called Special Law on Decent Shelter (Decree $n^{\circ} 8001$ of 2011) to protect populations in case of emergencies and disasters.

Colombia enacted Decree $n^{\circ} 4674$ of 2010, which establishes norms on evacuation of persons and has provisions on the implementation of relocation programs (art.3, e), identifying entities which are to be responsible for the preparing of a resettlement program (art.3, i) and providing technical assistance for families that live in high risk areas (art.3, f).

Children, elderly people and people with disabilities are especially vulnerable in the context of disasters. In the case of people with disabilities, this vulnerability originates from personal characteristics, for instance mobility and sensory disabilities, added to the lack of shelters or accessible transportation (Ghenis, 2016). Brazil enacted the Ministerial Decree $\mathrm{n}^{\circ}$ 2 of 2012 which establishes the National Collective Protocol for the Integral Protection of Children and Teenagers, Elderly People and People with Disabilities in Situations of Risk of Disasters. This instrument addresses the protection of vulnerable groups during displacement and evacuation, constituting one of the few good practices in the world that provides special protection to these vulnerable people (Ramos et al., 2016).

Some hazards such as the eruption of the volcano Chaitén in Chile in 2008 required immediate action from the government. The central authorities established direct management and scientific teams that guided the evacuation. Although the evacuation of about 8,000 people was carried out without any casualties, and a continuous supporting program assisted the displaced population (Mandujano et al., 2015), it was claimed that the resettlement of the community did not take into consideration communities values, needs and expectations, which disrupted the lives of the inhabitants of Chaitén (Larenas et al., 2015). That demonstrates that it is essential that the affected communities are consulted at all displacement stages.

Assistance played an essential role to assist communities in Peru during the floods in 2012 in Loreto. The International Organization for Migrations (IOM) and local government of Loreto coordinated the construction of shelters and worked on monitoring capacity building of civil servants. Campaigns against human trafficking and domestic violence were also carried out (MMPV and IOM, 2015).

\subsection{Human mobility in the national adaptation plans of South American states}

National Adaptation Plans are instruments provided for in the Cancun Adaptation Framework. Their objectives are:

- to reduce vulnerability to the impacts of climate change, by building adaptive capacity and resilience; and

- to facilitate the integration of climate change adaptation into relevant new and existing policies, programmes and activities (Decision 5/CP.17, 2011).

Adaptation consists of a set of actions to provide response to actual or expected climate stimuli in the vulnerable system to moderate harm caused by climate change (McCarthy et al., 2001). Including human mobility in adaptation planning can prevent forced displacement and ensure that migration and planned relocation are addressed. Human 
mobility is relevant to adaptation since it can avoid the type of displacement that harms human welfare (Warner et al., 2015). Migration can be seen as adaptation because it can reduce population pressures in places prone to climate risks (McLeman and Hunter, 2010), diversifies sources of income that can increase the resilience of communities and remittances can provide support in the wake of disasters (Gemenne and Blocher, 2017). Planned relocation (Warner et al., 2015) can represent an opportunity to diversify the forms of displacement towards new areas and can be used to increase/enhance resilience in the home country (Ober, n.d.).

Most of referrals of migration in NAPs in the world focus on the negative impacts of climate change and intend to limit rural-to-urban migration, though a few identify planned relocation to avoid future impacts (Warner et al., 2015). Nevertheless, they lack strategies to prevent human mobility.

While Argentina, Bolivia, Guyana, Paraguay, Peru, Suriname, Uruguay and Venezuela are still elaborating their NAPs, Brazil, Colombia and Chile have already developed their own instruments. These countries recognize, albeit briefly, the linkage between migration and climate change. Colombia and Chile consider migration as a result of the negative impacts of climate change. Colombia notes that migration and displacement affect not only the poorest persons but also populations settled in risky areas, demonstrating a reactive perspective on migration. Besides, Chile links extreme hydrometeorological events to the increase of infectious diseases and allergic injuries, which leads to migration. In this context, it is important to note that Brazil's NAPs is the only one to mention migration as a possible adaptation strategy to the adverse effects of climate change. The Brazilian National Adaptation Plan (NAP), launched in May 2016, recognized that the increase of temperature may increase the risk of extreme events in several regions of Brazil, such as droughts and floods which may cause displacement of people from affected areas. It states that there is the "possibility of new migratory flows in response to the negative consequences to climate change and as a "possible strategy of adaptation" to climate change, but it does not explain how migration could be considered an adaptation strategy. In addition, it states that it should "measures to enhance understanding, coordination and cooperation with regard to climate change induced displacement, migration and planned relocation [...] at national, regional and international levels" should be taken. However, the term migration is mentioned only once in Chile's and Colombia's NAPs.

\section{Conclusions}

Human mobility in the context of disasters and climate change in South American states endangers the lives of millions of people and their livelihoods. Disasters are important triggers of displacement and affect human mobility in the region.

There are some relevant international instruments that pointed out the need to address the protection of people and communities displaced in the context of disasters related, or not, to climate change. In fact, the international community as a whole appears to be attempting to integrate human mobility in the frameworks of action regarding DRR and climate change, as seen in the Sendai Framework and Paris Agreement.

To implement the topic of human mobility in the context of disasters into national domestic policies and norms, it is necessary that countries promote harmonization and better coordination between their DRR and climate change norms and policies in topics concerning human mobility, and of these national instruments with international guidelines. This can be achieved through the revision and adoption of this issue in the national DRR law and policies, NAPs and INDCs/NDCs. 
IJCCSM 10,1

This study finds that few South American countries include human mobility as a strategic topic in their climate policies and norms, with many others lacking such an approach, and provides examples of the inclusion of strategies on pre-displacement, displacement and post-displacement phases which take place in countries of this region.

However, some advances with regards to human mobility are confirmed at the domestic level of South American countries, from humanitarian visas to disaster-displaced persons and the inclusion of the topic in the DRR, climate change laws, NAPs and INDCs/NDCs. The different levels of achievement regarding human mobility in the context of disasters and climate change in national norms and policies are influenced by a range of factors. But the confrontation to real situations of disaster displacement as states of origin or hosting displaced persons seems to be the central factor that motivates states to consider human mobility in these norms and policies. The absence of clear, specific and compiled data concerning displacement in the context of disasters and climate change in the region, as well as the weak knowledge and comprehension by governments of the relationship between disasters, climate change and human mobility, are major obstacles to making advances in integrating human mobility in DDR and climate change norms and policies. Even if some advances were identified, states have not developed specific strategies with regards to it. Hence, to make more substantial advances, it is necessary that national norms and policies are aligned with international guidelines. This will enable to fill the identified protection gaps of people in the context of disasters and climate change.

Some measures can contribute to reinforce the consideration of human mobility in the context of DRR and climate change national laws and policies:

- better articulation and coordination between national norms and policies concerning DRR and climate change;

- alignment of these norms and policies with the recommendations of the Sendai Framework and the UNFCCC's directives concerning human mobility, especially the recommendations that will be made by the UNFCCC's Task Force on Displacement;

- recognize and develop migration as an adaptation strategy, especially in the National Adaptation Plans;

- adopt international guidelines as the basis to revise existing norms and policies or to adopt new ones that are adequate to deal with human mobility in the context of disasters and climate change; and

- $\quad$ produce more and better data concerning displacement in the context of disasters and climate change in the region to support and inform governments action.

\section{Notes}

1. [Fourth Regional Platform for the DRR in the Americas (Ecuador, May 2014), Regional Thematic Consultation on Disasters Risk Reduction and Climate Change Adaptation (Panamá, May 2014), UNASUR: Sub-regional consultation on the new international framework of disaster risk reduction post 2015 (Chile, April 2014), Regional project: Perspectives in the implementation of MAH in South America (Peru, November 2013), Consultation post 2015 in the 7th Annual Caribbean Conference on comprehensive disaster management (Jamaica, December/January 2013), Regional Platform for the DRR in the Americas - 2012 (Chile, November 2012). Fifth Regional Platform for Disaster Risk Reduction (Canada, March, 2017)]

2. [The implementation of the Task Force on displacements caused by the adverse effects of climate change is under the responsibility of the Executive Committee of the International Mechanism of 
Warsaw for Loss and Damages. Among the strategic action areas of the work plan of the Executive Committee (which lasts five years), there is migration, displacement and human mobility, including a Task Force on Displacement. Its initial plan (2015-2016) already provided a specific work area about the topic (work area 6), which aimed to enhance the understanding and knowledge on climate change impacts and how they are affecting migration patterns, displacement and human mobility.]

\section{References}

Advisory Group on Climate Change and Human Mobility (2015), Human Mobility in the Context of Climate Change - Elements for the UNFCCC Paris Agreement 2015, available at: www.unhcr. org/5550ab359.pdf (accessed 5 March 2017).

Agenda for the Protection of Cross-Border Displaced Persons in the Context of Disasters and Climate Change (2015), available at: https://nanseninitiative.org/wp-content/uploads/2015/02/ PROTECTION-AGENDA-VOLUME-1.pdf (accessed 10 March 2017).

Álvarez, J.R. (2016), Analysis on the Evolution of Disaster Management Policies and legislations in four countries of South America: Chile, Colombia, Peru and Venezuela, Erasmus Mundus Master Course in Public Health in Disasters, Oviedo, available at: http://pubhealthdisasters.eu/wpcontent/uploads/2016/08/Master-thesis-Jhon-Rangel-submit-20-jul.pdf (accessed 1 March 2017).

Asunción Declaration: Guidelines Towards a Regional Action Plan on the Implementation of the Sendai Framework in the Americas (2016), available at: www.preventionweb.net/english/professional/ policies/v.php?id=49235 (accessed 8 March 2017).

Brookings Institute, London School of Economics (2014), Climate Change and Internal Displacement, Brookings Institute, London School of Economics, Washington, DC, available at: www.brookings. edu/wp-content/uploads/2016/06/Climate-Change-and-Internal-Displacement-October-10-2014.pdf (accessed 10 March 2017).

Bronen, R. (2015), "Climate-induced community relocations: using integrated social-ecological assessments to foster adaptation and resilience", Ecology and Society, Vol. 20 No. 3, pp. 36-43.

Brugnoni, P. (2012), "El Sistema Nacional de Emergencias y la Gestión de Emergencias y la Gestión del Riesgo de Desastres en Uruguay", Sistema Nacional de Emergencias, AÑO 7 - No. 51, pp. 22-28.

Camp Coordination and Camp Management Cluster (n.d.), The Mend Guide Comprehensive Guide for Planning Mass Evacuations in Natural Disasters -Pilot Document, available at: www. globalcccmcluster.org/system/files/publications/MEND_download.pdf (accessed 9 March 2017).

Cancun (2010), UNFCCC, Cancun Agreements Outcome of the Work of the Ad Hoc Working Group on Long-term Cooperative Action Under the Convention, available at: https://unfccc.int/resource/ docs/2010/cop16/eng/07a01.pdf (accessed 17 March 2017).

Cantor, D. (2016), "Migrants and natural disasters: national law, policy and practice in the Americas, migration, environment and climate change", IOM Policy Brief Series, Vol. 2, available at: https:// publications.iom.int/system/files/pdf/policy_brief_vol2_issue2.pdf (accessed 12 March 2017).

Cartagena Declaration on Refugees (1984), available at: www.refworld.org/docid/3ae6b36ec.html (accessed 12 June 2017).

Chazalnoël, M.T. and Mach, E. (2016), Migration in INDCs/NDCs, available at: www. environmentalmigration.iom.int/migration-indesndes (accessed 9 March 2017).

Climate Policy Observer (n.d.), INDC, available at: http://climateobserver.org/open-and-shut/indc/ (accessed 12 March 2017).

Colombia INDC (2015), UNFCCC, available at: www4.unfccc.int/submissions/INDC/Published $\% 20$ Documents/Colombia/1/Colombia\%20iNDC\%20Unofficial\%20translation\%20Eng.pdf (accessed 7 March 2017). 
IJCCSM

10,1

Ferris, E. (2014), Planned Relocations, Disasters and Climate Change: Consolidating Good Practices and Preparing for the Future, Background Document, Sanremo Consultation, Brookings-LSE Project, Washington, DC, available at: www.unhcr.org/53c4d6f99.pdf (accessed 7 March 2017).

Gemenne, F. and Blocher, J. (2017), "How can migration serve adaptation to climate change? Challenges to fleshing out a policy ideal", The Geographical Journal, pp. 1-12, doi: 10.1111/geoj.12205, available at: http://onlinelibrary.wiley.com/doi/10.1111/geoj.12205/epdf (accessed 5 March 2017).

Ghenis, A. (2016), "Making migration accessible: Inclusive relocation for people with disabilities, migration, environment and climate change", IOM Policy Brief Series, Vol. 2, available at: https://publications.iom.int/system/files/pdf/policy_brief_series_vol2_issue6_2_0.pdf (accessed 8 March 217).

Global Platform for Disaster Risk Reduction (2017), The Cancun High-Level Communiqué - Ensuring the resilience of infrastructure and housing, available at: www.preventionweb.net/files/ 53439_thecancunhighlevelcommuniquof24may2.pdf (accessed 16 June 2017).

Guadagno, L. (2016a), "Human mobility in the sendai framework for disaster risk reduction", International Journal of Disaster Risk Science, Vol. 7. pp. 30-40.

Guadagno, L. (2016b), "Reducing migrants' vulnerability to natural disasters through disaster risk reduction measures including migrants in disaster prevention, preparedness, response and recovery efforts, migrants in countries in crisis initiative", Issue Brief, available at: https:// micicinitiative.iom.int/sites/default/files/resource_pub/docs/micic_issue_briefs_1_drr_final.pdf (accessed 5 March 2017).

Guadagno, L. (2017), "Human mobility in a socio-environmental context: complex effects on environmental risk", in Sudmeir-Rieux, K., Fernández, M., Penna, I., Jaboyedoff, M. and Gaillard, J. (Eds), Identifying Emerging Issues in Disaster Risk Reduction, Migration, Climate Change and Sustainable Development-Shapind Debate and Policies, Springer, Heidelberg, pp. 13-31.

Hugo, G. (2010), "Climate change-induced mobility and the existing migration regime in Asia and the Pacific", in McAdam, J. (Ed.), Climate Change and Displacement, Multidisciplinary Perspectives, Hart Publishing, Oxford, Portland, pp. 12-15.

ICMPD (2016), Migrants in Countries in Crisis - Consultation Report MICIC Regional Consultation for Latin America and the Caribbean San José, available at: https:/micicinitiative.iom.int/sites/ default/files/document/consultation_report_english_1.pdf (accessed 7 March 2017).

IDMC and NRC (2016), Global Report on Internal Displacement, available at: www.internaldisplacement.org/assets/publications/2016/2016-global-report-internal-displacement-IDMC.pdf (accessed 5 March 2017).

IDMC and NRC (2017), Global Report on Internal Displacement, available at: www.internaldisplacement.org/assets/publications/2017/20170522-GRID.pdf (accessed 16 June 2017).

IDMC (2017), Positioned for Action-Displacement in the Sendai Framework for Disaster Risk Reduction, available at: www.internal-displacement.org/assets/publications/2017/20170216-idmc-briefingpaper-drr.pdf (accessed 5 March 2017).

IFRC and UNDP (2014), Effective law and regulation for disaster risk reduction: a multi-country report, available at: www.ifrc.org/PageFiles/125735/drr.law\%20report\%20(compressed).pdf (accessed 10 March 2017)

IFRC and SKAT (2012), Sustainable Reconstruction in Urban Areas-A Handbook, available at: www. ifrc.org/PageFiles/95526/publications/Urban \%20reconstruction \%20Handbook \%20IFRC-SKAT. pdf (accessed 10 March 2017).

IOM (2015), IOM Contributions to the 'year of climate': 21st Conference of Parties of the United Nations Framework Convention on Climate Change (UNFCCC), Organized by Dina Ionesco and Mariam Traore Chzanoël, available at: www.environmentalmigration.iom.int/ (accessed 10 March 2017).

IPCC (2014), "Climate change 2014: impacts, adaptation, and vulnerability: Part A: global and sectoral aspects", Contribution of Working Group II to the Fifth Assessment Report of the 
Intergovernmental Panel on Climate Change, Cambridge University Press, Cambridge, New York, NY.

Kaenzig, R. and Piguet, E. (2014), "Migration and climate change in America and the Caribbean", in Piguet, E. and Laczko, F. (Eds), People on the Move in a Changing Climate, Global Migration Issues 2, Springer, Heidelberg, pp. 155-176.

Krippendorff, K. (2013), Content Analysis: An Introduction to its Methodology, Sage Publications, Los Angeles, CA.

Larenas, J.A., Salgado, M.A. and Fuster, X.S. (2015), "Enfrentar los desastres socionaturales desde los capitales y recursos comunitários: el caso de la erupción volcánica de Chaitén, Chile", Magallania, Vol. 3 No. 3, pp. 125-139.

Ley de Gestión de Riesgos (Bolívia) (2014), Ley n ${ }^{\circ} 602,14$ Noviembre 2014, available at: www.ifrc.org/docs/ IDRL/South\%20America/LEY\%20DE\%20GESTI\%C3\%93N\%20DE\%20RIESGOS-\%20Bolivia. pdf (accessed 10 March 2017).

Ley de Gestión Integral de Riesgos Socionaturales y Tecnológicos (Venezuela) (2009), Ley n 39.095, 9 de enero de 2009, available at: www.ifrc.org/docs/IDRL/Venezuela-ley_G.I.R.S.T.pdf (accessed 10 March 2017).

Ley del Sistema de Defensa Civil (Colombia) (1972), Decreto Presidencial n 19338, 28 Marzo 1972, available at: http://sinpad.indeci.gob.pe/UploadPortalSINPAD/ley $\% 2019338 \% 20$ texto $\% 20$ ordenado\%201ey \%20del\%20sinadeci.pdf (accessed 10 March 2017).

Ley de Migración (Bolívia) (2013), Ley n 370, 8 Mayo 2013, available at: www.la-razon.com/nacional/ Ley-Migracion_LRZFIL20150324_0005.htm (accessed 10 March 2017).

Ley Especial de Refugios Dignos (Venezuela) (2011), Decreto n 8001, 21 enero 2011, available at: www.mpppst.gob.ve/mpppstweb/wp-content/uploads/2014/03/LEY_ESPECIAL_DE_REFUGIOS_ DIGNOS.pdf (accessed 10 March 2017).

Ley que crea el sistema nacional de gestión de riesgo de desastres (SINAGERD) (Perú) (2011), Ley n ${ }^{\circ}$ 29664, 9 Febrero 2011, available at: www.cenepred.gob.pe/web/es/data/pdf/Ley_SINAGERD.pdf (accessed 9 March 2017).

McAdam, J. (2016), "From the Nansen initiative to the platform on disaster displacement: shaping international approaches to climate change, disasters and displacement", University of South Wales Law Journal, Vol. 34 No. 9, pp. 1518-1546.

McCarthy, J.J., Canziani, O.F., Leary, N.A., Dokken, D.J. and White, K.S. (Eds) (2001), Climate Change: Impacts, Adaptation and Vulnerability, Cambridge University Press, Cambridge.

McLeman, R.A. and Hunter, L.M. (2010), "Migration in the context of vulnerability and adaptation to climate change: insights from analogues", Climate Change, Vol. 1pp. 450-461.

Mandujano, F., Rodríguez, J.C., Reyes, S.E. and Medina, P. (2015), "La erupción del volcán chaitén: Voyerismo, desconfianza, academia y estado: consecuencias urbanas y sociales en la comunidade", Universum (Talca), Vol. 30 No. 2, pp. 153-177.

Marengo, J.A., Borma, L.S., Rodriguez, D.A., Pinho, P., Soares, W.R. and Alves, L.M. (2013), "Recent extremes of drought and flooding in Amazonia: vulnerabilities and human adaptation", American Journal of Climate Change, Vol. 02 No. 2, pp. 87-96.

Marrakech (2016), UNFCCC. The 22nd Conference of Parties (COP22), Marrakesh, 7-18 November 2016.

MERCOSUR (2015), "Las Cumbres Sociales del Mercosur II: Declaraciones y Documentos de Trabajo", available at: www.mercosur.int/innovaportal/file/7117/1/las-cumbres-sociales-del-mercosur-iideclaraciones-y-documentos-de-trabajo.pdf (accessed 12 June 2017).

MMPV and IOM (2015), Ministerio de La Mujer y de las Poblaciones Vulnerables y Organización Internacional para las Migraciones (2015) Desplazamientos internos en Perú, available at: www. oimperu.org/sitehome/sites/default/files/Documentos/Desplazamientos_Internos.pdf (accessed 16 June 2017). 
IJCCSM 10,1

Nansen Initiative (2015), Movilidad humana en el contexto de desastres y cambio climático en América del Sur, Informe del Taller Regional en América del Sur de la Iniciativa Nansen y el Refugee Law Initiative de la Universidad de Londres, Quito.

National Fund for Calamities (1984), Colombia, Decreto $n^{\circ} 1547$ de 1984. Fondo Nacional de Calamidades, available at: www.suin-juriscol.gov.co/viewDocument.asp?id=1307093 (accessed 8 March 2017).

Peninsula Principles (2013), Displacement Solutions (2013) The Peninsula Principles on Climate Displacement Within States, available at: http:/displacementsolutions.org/peninsula-principles/ (accessed 8 March 2017).

Ober, L. (n.d.), Migration as Adaptation-Exploring Mobility as a Coping Strategy for Climate Change, The UK Climate Change and Migration Coalition, available at: http://climatemigration.org.uk/ wp-content/uploads/2014/02/migration_adaptation_climate.pdf (accessed 5 March 2017).

OIM (2014), Migración, Medio Ambiente y Cambio Climático: Una Introducción - Conceptos, Terminología y Situación Actual en América del Sur, Oficina Regional para América del Sur, Buenos Aires.

OIM (2015), “Taller de capacitación para América del Sur: "Migración, Medio Ambiente y Cambio Climático" - Relatoría”, available at: https:/environmentalmigration.iom.int/sites/default/ files/Relatoria $\% 20$ Migraci $\%$ C3 $\%$ B3n $\% 20$ Ambiente $\% 20 y \% 20 \mathrm{CC} \% 20 \% 2013 \mathrm{Fac} \% 20$ version $\% 20$ digital.pdf (accessed 10 June 2017).

Oliver-Smith, A. and de Sherbinin, A. (2014), "Resettlement in the twenty-first century", Forced Migration Review, No. 45, pp. 23-25.

Paris Agreement (2015), opened for signature 22 April 2016, entered into force 4 November 2016.

Pivetta, M. (2016), "50 Anos de Calamidades na América do Sul”, Revista Pesquisa FAPESP, No. 241, pp. 62-65.

Platform for Disaster Displacement (2017), Disaster displacement and disaster risk reduction" to inform the Global Platform for DRR, Cancún, Mexico, 22-26 May 2017, available at: http:// disasterdisplacement.org/disaster-displacement-at-gp17/ (accessed 16 June 2017).

Por el Cual se Dictan Normas Sobre Evacuación de Personas y se Adoptan Otras Medidas (Colombia) (2010), Decreto Presidencial n ${ }^{\circ} .4674,17$ Deciembre 2010, available at: www.colombiahumanitaria. gov.co/Apoyo/Documents/decretos/dec467417122010.pdf (accessed 10 March 2017)

Por el Cual se Adopta la Política Nacional de Gestión del Riesgo de Desastres y se Establece el Sistema Nacional de Gestión del Riesgo de Desastres y se Dictan otras Disposiciones (Colombia) (2012), Ley n ${ }^{\circ}$ 1523, 24 Abril 2012, available at: www.ifrc.org/docs/idrl/1057ES.pdf (accessed 10 March 2017).

Por el Cual se Crea el Fondo Nacional de Calamidades y se dictan normas para su organización y funcionamiento (Colombia) (1984), Decreto Presidencial n 1547, 21 Junio 1984, available at: www.bvsde.paho.org/bvsacd/cd38/Colombia/D1547-84.pdf (accessed 12 March 2017).

Por el Cual se Dictan Normas Sobre Evacuación de Personas y se Adoptan Otras Medidas (Colombia) (2010), Decreto $n^{\circ} 4674,17$ Deciembre 2010, available at: www.secretariasenado.gov.co/senado/ basedoc/decreto_4674_2010.html (accessed 9 March 2017).

Ramos, E.P. Jubilut, L.L. Cavedon-Capdeville, F.S. and Claro, C.A. (2016), "Environmental migration in Brazil: current context and systemic challenges", available at: https:/publications.iom.int/ system/files/pdf/policy_brief_series_vol2_issue5_en.pdf (accessed 10 March 2017).

RESAMA (2016), Migración, medio ambiente y cambio climático: agenda 2030, buenas prácticas y desafíos para la región suramericana, XVI Conferencia Suramericana sobre Migraciones, available at: http:// csm-osumi.org/Archivos/ConfCSM/Documento $\% 20 \mathrm{de} \% 20$ referencia $\% 20-\% 20$ Migraci $\% \mathrm{C3} \% \mathrm{~B} 3 \mathrm{n}$, $\% 20$ medio $\% 20$ ambiente $\% 20$ y $\% 20$ cambio $\% 20$ clim \%C3\%A1tico.pdf (accessed 14 March 2017).

Richter, K.F., Shi, M., Gan, H.S. and Winter, S. (2013), "Decentralized evacuation management", Transportation Research Part CEmerging Technologies, Vol. 31, pp. 1-17. 
SDGs (2015), UNITED NATIONS, Department of Economic and Social Affairs, Population Division. Integrating migration into the 2030 Agenda for Sustainable Development, Population Facts, issue 2015/5, December 2015, available at: www.un.org/en/development/desa/population/ migration/publications/populationfacts/docs/MigrationPopFacts20155.pdf (accessed 8 March 2017).

Sendai Framework for Disaster Risk Reduction (2015), available at: www.unisdr.org/we/coordinate/ sendai-framework (accessed 8 March 2017).

Sistema Nacional de Prevención y Atención de Desastres (SNPAD) (2008), Colombia: Descentralización de las actividades de Reducción del Riesgo de Desastre, Colombia, June, available at: www.eird. org/wikies/images/Buena_Practicas_Colombia_-_13_06_08.pdf

Sistema Nacional de Emergencias (Uruguay) (2009), Law n ${ }^{\circ}$ 18621, 17 noviembre 2009, available at: https://legislativo.parlamento.gub.uy/temporales/leytemp9877381.htm (accessed 13 March 2017).

Suriname INDC UNFCCC (2015), available at: www4.unfccc.int/Submissions/INDC/Published\% 20Documents/Suriname/1/INDC-2-Suriname \% 20300915.pdf (accessed 10 March 2017).

Thiede, B., Gray, C. and Mueller, V. (2016), "Climate variability and inter-provincial migration in South America, 1970-2011”, Global Environmental Change, Vol. 41, pp. 228-240.

UNEP, OCHA (2012), "Keeping up with mega trends - the implications of climate change and urbanization for environmental emergency preparedness and response", available at: www. wcdrr.org/wcdrr-data/uploads/868/Keeping \% 20up $\% 20$ with $\% 20$ megatrends $\% 20$ - $\% 20$ The $\%$ 20implications $\% 20$ of $\% 20$ climate $\% 20$ change $\% 20$ and $\% 20$ urbanization $\% 20$ for $\% 20$ environmental \%20emergency \%20preparedness\%20and\%20response.pdf (accessed 12 June 2017).

UNEP, PARLATINO (2015), "Aportes Legislativos de América Latina y El Caribe en materia de Cambio Climatico", available at: www.pnuma.org/publicaciones/Aportes_legislativos_de_ALC_final.pdf (accessed 12 June 2017).

UNISDR (2015), "Land-use planning for disaster risk reduction-working session, 16 March", available at: www.wcdrr.org/wcdrr-data/uploads/868/Working $\% 20$ Session $\% 20$ Report $\% 20-\% 20$ Land-Use $\% 20$ Planning \%20for\%20Disaster\%20Risk\%20Reduction.Final.pdf (accessed 15 June 2017).

Uruguay INDC UNFCCC (2015), available at: www4.unfccc.int/submissions/INDC/Published\%20 Documents/Uruguay/1/INDC \%20Uruguay \%20(English-unofficial\%20translation).pdf (accessed 25 February 2017).

United Nations Framework Convention on Climate Change (1992), opened for signature, 4 June 1992, entered into force 21 March 1994.

Venezuela INDC UNFCCC (2015), available at: www4.unfccc.int/Submissions/INDC/Published\% 20Documents/Venezuela/1/Venezuela\%20Diciembre\%202015\%20(final).pdf (accessed 10 March 2017).

Warn, E. and Adamo, S.B. (2014), "The impact of climate change: migration and cities in South America”, World Meteorological Organization Bulletin, Vol. 63 No. 2, available at: https:/public.wmo.int/en/ resources/bulletin/impact-of-climate-change-migration-and-cities-south-america (accessed 12 June 2017).

Warner, K., Kalin, W., Martin, S. and Nassef, Y. (2015), "National adaptation plans and human mobility: disasters and displacement in a changing climate", Forced Migration Review, Vol. 49, pp. 8-9, available at: www.fmreview.org/climatechange-disasters/warner-kaelin-martin-nassef.html (accessed 27 February 2017).

Wilkinson, E., Kirbyshire, A., Mayhew, L., Batra, P. and Milan, A. (2016), "Climate-induced migration and displacement: closing the policy gap", ODI Briefing, available at: www.odi.org/sites/odi.org. uk/files/resource-documents/10996.pdf (accessed 12 March 2017).

World Bank (n.d.), "Guidance notes on tools for pollution management", available at: http://siteresources. worldbank.org/INTRANETENVIRONMENT/Resources/244351-1279901011064/GovLandUse Planning.pdf (accessed 12 June 2017). 
IJCCSM 10,1

Yamamoto, L. and Esteban, M. (2017), "Migration as an adaptation strategy for Atoll Island States", International Migration, Vol. 55 No. 2, pp. 144-158.

\section{Further reading}

A/CONF.206/6 (2005), Report of the World Conference on Disaster Reduction, Kobe, Hyogo, 18-22 January, available at: www.unisdr.org/2005/wcdr/intergover/official-doc/L-docs/Final-reportconference.pdf (accessed 12 June 2017).

Brasil, Ministério do Meio Ambiente, Plano Nacional de Adaptação à Mudança do Clima-Volume I: Estratégia Geral, Versão Consulta Pública (2015a), available at: http:/hotsite.mma.gov.br/ consultapublicapna/wp-content/uploads/sites/15/2015/08/PNA-Volume-1-05.10.15-Vers \%C3\%A3oconsulta-p\%C3\%BAblica.pdf (accessed 9 March 2017).

Brasil, Ministério do Meio Ambiente, Plano Nacional de Adaptação à Mudança do Clima-Volume II: Estratégias Setoriais e Temáticas, Versão Consulta Pública (2015b), available at: http://hotsite. mma.gov.br/consultapublicapna/wp-content/uploads/sites/15/2015/08/PNA_-Volume-2-07.10.15_ Consulta-P\%C3\%BAblica_texto-final.pdf (accessed 9 March 2017).

CELAG, Hacia el Sur. La Construcción de la Ciudadanía Suramericana y la movilidad intrarregional (2016), Jacques Ramirez Gallegos, available at: www.celag.org/wp-content/uploads/2016/10/ hacia-el-Sur_Vfinal-16-03-2.pdf (accessed 12 June 2017).

Cernadas, P.C. and Freier, L.F. (2015), "Migration policies and policymaking in Latin America and the Caribbean: lights and shadows in a region in transition", A Liberal Tide? Immigration and Asylum Law and Policy in Latin America, School of Advanced Study, University of London, London, pp. 11-32, available at: http://sas-space.sas.ac.uk/6152/1/05.\%20ALT_Ch1_Ceriani\% 20Cernadas_Feline \% 20Freier.pdf (accessed 10 March 2017).

Chile, Ministério del Medio Ambiente (2016), Plan Nacional de Adaptación al Cambio Climático, available at: http://portal.mma.gob.cl/wp-content/uploads/2016/02/Plan-Nacional-AdaptacionCambio-Climatico-version-final.pdf (accessed 9 March 2017).

Colombia, Ministerio del Medio Ambiente y Desarrollo Sostenible Plan Nacional de Adaptación al Cambio Climático (2017), available at: www.minambiente.gov.co/index.php/component/content/ article?id=476:plantilla-cambio-climatico-32. (accessed 9 March 2017).

CSM, 'Declaración de Santiago - Con Justicia e igualdad hacia una gobernanza migratoria' (2015), available at: http://csmosumi.org/Archivos/ConfCSM/XV\%20CSM_\%20DECLARACI\%C3\% 93N\%20DE \%20SANTIAGO \%20(2015).pdf (accessed 12 June 2017).

CSM, 'Declaración de Asunción - Hacia el Libre Tránsito' (2016), available at: http://csm-osumi.org/ Archivos/ConfCSM/1\%20Declar\%20ASUNCION\%202016\%20escan.pdf (accessed 12 June 2017).

Decreto Legislativo de Migraciones (Perú) (2015), Decreto n 1236, 26 setiembre 2015, available at: www.elperuano.com.pe/NormasElperuano/2015/09/26/1292707-6.html (accessed 14 March 2017).

Decreto Reglamentario de la ley $\mathrm{n}^{\circ} 25.871$ Sobre Política Migratória Argentina (Argentina) (2010), Decreto ${ }^{\circ}$ 616, 3 mayo 2010, available at: www.ilo.org/dyn/natlex/docs/ELECTRONIC/83735/ 92694/F304346842/ARG83735.pdf (accessed 12 March 2017).

Displacement Solutions (2013), "The Peninsula principles on climate displacement within states", available at: http://displacementsolutions.org/wp-content/uploads/2014/12/Peninsula-Principles. pdf (accessed 5 March 2017).

Ecuador INDC (2015), UNFCCC, available at: www4.unfccc.int/submissions/INDC/Published\% 20Documents/Ecuador/1/Ecuador \%20INDC \% 2001-10-2015\%20-\%20english \%20unofficial $\%$ 20translation.pdf (accessed 7 March 2017).

Fija Disposiciones Para Casos de Sismos o Catastrofes Establece Normas Para la Reconstrucción de la Zona Afectada Por el Sismo de (1965), 18 marco de 1965 y nodifica la ley n¹6250. (Chile), Ley n 
16262, 28 Marzo 1965, available at: www.leychile.cl/Navegar?idNorma=214428 (accessed 15 March 2017).

Institui o Protocolo Nacional Conjunto para Proteção Integral a Crianças e Adolescentes, Pessoas Idosas e Pessoas com Deficiência em Situação de Riscos e Desastres (Brasil) (2012), Portaria Interministerial $\mathrm{n}^{\circ}$ 2, 6 dezembro 2012, available at: www.lex.com.br/legis_24042581_ PORTARIA_INTERMINISTERIAL_N_2_DE_6 (accessed 15 March 2017).

IOM (2014), Migration, Environment and Climate Change: Evidence for Policy (MECLEP) - Glossary, available at: $\mathrm{http} / /$ publications.iom.int/system/files/pdf/meclep_glossary_en.pdf?language=en (accessed 12 June 2017).

Ministerio de la Mujer y Poblaciones Vulnerables y Organización Internacional para las Migraciones (2015), "Desplazamientos Internos em el Perú", available at: www.oimperu.org/sitehome/sites/ default/files/Documentos/Desplazamientos_Internos.pdf (accessed 16 June 2017).

Wentz, J. (2016), "Developing an agenda for the protection of persons displaced by disasters and climate change", 20 October, available at: http://blogs.law.columbia.edu/climatechange/2016/10/20/ developing-an-agenda-for-the-protection-of-persons-displaced-by-disasters-and-climate-change/ (accessed 20 February 2017).

UNHCR (2013), "Expert roundtable interpretation of the extended refugee definition contained in the 1984 Cartagena Declaration on Refugees Montevideo, Uruguay 15 and 16 October 2013”, available at: www.unhcr.org/53bd4d0c9.pdf (accessed 12 June 2017).

UNISDR (2017a), "Sendai framework for disaster risk reduction”, available at: www.unisdr.org/we/ coordinate/sendai-framework (accessed 8 March 2017).

UNISDR (2017b), "Fifth regional platform for disaster risk reduction in the Americas", available at: http://eird.org/rp17/docs/virtual-brochure.pdf (accessed 8 March 2017).

\section{About the authors}

Lilian Yamamoto is a $\mathrm{PhD}$ in international law at Kanagawa University, Japan; member of RESAMA (South American Network for Environmental Migrations); and co-author of the book Atoll Island States and International Law-climate change displacement and sovereignty (2014), Springer. Lilian Yamamoto is the corresponding author and can be contacted at: lilianmitsuko@yahoo.it

Diogo Andreola Serraglio is a $\mathrm{PhD}$ Student in law at Pontifícia Universidade Católica do Paraná (PUCPR), Brazil; fellow of the Coordination of Improvement of Higher Education Personnel Scholarship (CAPES); MD in Economic and Environmental Law at PUCPR; specialized in International Environmental Law at the U.N. Institute for Training and Research (UNITAR) and Environmental Law at Paraná Federal University (UFPR); and member of the International Union for the Conservation of Nature (IUCN) and of the South American Network for Environmental Migrations (RESAMA); Lawyer.

Fernanda de Salles Cavedon-Capdeville is a $\mathrm{PhD}$ in environmental law at Alicante University, Spain; former postdoctoral fellow at University of Limoges, France; member of RESAMA (South American Network for Environmental Migrations) and of International Center of Comparative Environmental Law (CIDCE).

For instructions on how to order reprints of this article, please visit our website:

www.emeraldgrouppublishing.com/licensing/reprints.htm

Or contact us for further details: permissions@emeraldinsight.com 